on the terms $I$ have stated. Those who have been in practice a shorter time may be submitted to an examination before admittance, upon the same plan that the members are admitted to the fellowship. The College would then, in time, be able to boast of having within their pale all the general practitioners in the country, and the long-talked-of new College might be dispensed with, and the Apothecaries' Society could still retain their present powers. I think Sir George Grey may then be able to grant the two Colleges a new charter to each, and have but little difficulty in passing a legislative measure that would unite and legalize the medical and surgical corporate bodies. These old medical institutions cannot expect to gain much, without giving a little. Much that was included in medical reform is now set at rest by the jurisdiction of the County Courts. The dormant powers of the Apothecaries' Act are now bronght into light, and in this Court the Society can prosecute the illegal and the unqualified medical practitioner-even the follows or members of the Royal College of Surgeons, if they practise medicine without their licence-without much trouble or expense. This is a power that the College of Surgeons cannot exercise over those who may choose to practise or call themselves surgeons. This the Council of the College know, and must feel; but I think they ought to have the controling power over the practice of surgeons. It is very annoying to a young mant to find that when he has spent his money, and obtained his diploma by hard study, and started in practice, that another who has neither spent his time nor money may assume the same title, and practise surgery with impunity, which neither the Royal College of Surgeons nor the laws of the land can prevent. This was clearly proved at the last Somerset assizes, when a medical man, who had been in practice nearly thirty years, and who only held the licence of the Apothecaries' Society as his qualification, was examined as a witness in a very important case, involving surgical and pathological knowledge, and the counsel for the prisoner objected to his evidence because he was not a member of the College of Surgeons. This was overruled by the judge, who said at the time the witness began practice one-half of the medical men held no qualification at all. This medical witness has a good practice in Bath, is much respected by all his professional brethren, and stands high with them as to his anatomical, pathological, and other scientific acquirements; and yet this gentleman was held up, in a public crowded court, as one unfit to give evidence on such subjects, because he could not boast of having in his possession a valueless piece of paper. Such foolery as this should be put a stop to, and the Council of the Royal College are the parties that ought to do it; and if they wish to do it in a high and honourable manner, they should select, say a hundred of the most celebrated in practice without their diploma, and admits them as members, as they did their old members to the fellowship.

Bath, June, 1851. Yours \&c. Argus.

\section{DR. MURPHY AND THE NORWICH CONSULTATION.}

To the Editor of THe LANCET.

SIR,-I have no desire to enter upon a personal quarrel with Dr. Murphy : the little I saw of him left an extremely agreeable impression upon my mind; he appeared to be a mild, gentlemanly, and courteous man: but he has accused me of signing " two attestations perfectly contradictory to, and irreconcileable with each other;" and to meet this most serious charge brought against me, I hope you will afford me a small space in your next paper. I did sign two statements : they were drawn up by two different persons, each bringing out in bolder relief those points in the case with which he had more immediately to do : there will necessarily therefore be a difference in the form and mode of expression; but as to the facts, to which alone (as I have before said) I am competent to testify, I must request Dr. Murphy to point out the contradiction, for I am convinced nonc exists.

Nevertheless, if from the distressed state of my feelings, arising from the mental anguish under which $I$ was at the time suffering, or from my earnest desire to avoid giving offence, or doing an injury to any one, I may have been betrayed into any contradictory expression, to which Dr. Murphy may be able to direct attention; then, instead of fencing with the difficulty, I will, God helping me, do what I venture to recommend as a prudent course to Dr. Murphy, namely, frankly confess that I have unintentionally given a mistaken opinion.

Surely, Sir, professing as he does such regard for my "high and sacred" calling and my lacerated feelings, Dr. Murphy could hardly have adopted a more effectual mode of increasing the acuteness of my suffering, than by thus attacking my character for truthfulness, and whilst much increasing the severity of my trial, holding back the documents upon which he rested his charge, on the ground of professed delicacy towards me.

I have only further to add, that it is most unjust towards me to say that Dr. Bell was "rather uncourteously dismissed;" whatever may be the merits of the case, my desire and practice towards him were, I believe, such as altogether contradict that statement. There are other portions of Dr. Murphy's letter affecting me, which I am not careful to notice.

Norwich, June 10, 1851

I remain, $\mathrm{Sir}$, very obediently yours, JoHN E. GLADSTONE.

\section{THE NEW MEDICAL COLLEGE, To the Editor of Trme LaAcer.}

SIR,-In common with many of my professional brethren, $\mathbf{I}$ rejoice that the time has arrived when there appears a prospect of union amongst our hitherto disunited profession,-- for the just and honourable purpose of obtaining a fair reward for their labours from those who can afford to remunerate them, but who have not common honesty, - and the establishment of a noble institution for the education of the sons of medical men, together with an asylum for the unfortunate. Although only a looker-on, I cannot contemplate such a plan of practical benevolence, conceived in so truly liberal a spirit that the recipient of the bounty may accept it without a feeling of degradation, too often entailed on those compelled to eat the bread of charity, however elevated their past position may have been, however honourable the efforts they have made to obtain independence : we shonld all remember "the battle is not always to the strong;" it is proverbial that those whose lives have been most earnestly devoted to science, like the choice spirits of some other classes of men, are those whose latter days are most frequently embittered by want, whose widows are left in helpless penury, whose children are ruined for want of education : I say I cannot contemplate the glorious efforts now making (headed by the warm-hearted and disinterested Mr. Probert), without expressing my surprise that a few gentlemen, members of our own common profession, who may be respectable, but whose names and responsibility are unknown, and whose power is therefore insignificant, should be canvassing for members in support of a society, as they term themselves, for the mere collection of debts, in open opposition to Mr. Probert and his friends. How can any one oppose an obstacle to an undertaking, of far greater importance than any yet conceived for the benefit of the profession, which will exalt it in public opinion, which will confer honour on all its promoters, and give to its author an imperishable and truly enviable name.

T. W.

\section{THE OXIDE OF SILVER AND UTERINE H FMORRHAGE.}

To the Editor of THE LANCET.

Sre,-It is impossible for me, on reading the very interesting case of polypus of the uterus, by Mr. Chapman of Lower Tooting, in your last number, not to regret that that gentleman had not heard of the oxide of silver, or, if having heard of it, that he did not venture to employ it in restraining the almost constant uterine hæmorrhage, which, although she recovered, caused the patient to be "anæmiated and emaciated." How many years more will be required to convince the profession that in all cases of passive hæmorrhage, especially in that from the womb, whether that organ contains a polypus or a foetus, they have the remedy in their own hands? If they will not believe one who can have no motive in misleading them-one who, at an advanced stage of a long professional life, dares any one to deny that he has been always faithful to his order and to his brethren-who, after a daily study, during nearly ten years, of the qualities of the oxide of silver, has only the good of his fellow-creatures in view when he proclaims, at much trouble and some pecuniary cost, as he has done more than once, the result of his anxious industry to his fellowlabourers in the vineyard-they must submit to be taught by him from time to time, till they consent to receive the evidence of one who has their best interests at heart, though he may be, perchance, a stranger - of one who would have gratefully thanked any friend for like information previous to the 10th of July, 1841; when, while searching for help, he first 
read of the oxide in Thn LANCET, and which perfectly safe preparation is a specific, if there be one, in the slow bleedings which inevitably lead to disease and death. Two formal reports of its qualities have, at an interval of six years, been given to medical men, who, as the highly gifted author of Household Words (in allusion to other discoveries), under the article of chloroform, well says, "are slow to adopt a new remedy, partly from an unwillingness to be instructed, and partly from that conservative instinct, which in some minds supplies the place of intelligent circumspection, as a safeguard against the dangers of innovation."

Lower Brook-street, June 1851 . I am, Sir, your faithful servant, J AMES EYRE, M.D.

\section{THE MEDICAL PROFESSION AND THE LIFE ASSURANCE OFFICES. \\ The Sun Life Offioe.}

Mr. PaIntar, of Westminster, some time since forwarded to us the following correspondence:-

I received (he says) a list of seventeen questions respecting the health of Mr. A- the last of which ran thus,- "Do you know of any circumstance which may be considered as tending to shorten his life, or render an assurance on it more than usually hazardous?" To that letter the following was my reply:-

“4, Broadway, Westminster.

"Sin,-I have received your letter of queries respecting the health of my friend, Mr. $\AA$ - and on your remitting me the usual fee of one guinea I will answer them. In the event of your declining to do so, I shall feel it a duty incumbent on me (for the benefit of the profession) to recommend him to apply to some office that pays the medical referee.

"To C. Lidderdale, Esq."

"I am, \&c.,

"Richard Painter."

I heard no more about the matter till I received the following, at nine P.M. on the 5th of the ensuing month:-

"Sun Life Office, 1850.

"Sin,-In reply to your letter of the 30th ultimo, I beg to state to you that the managers decline paying any fee to the medical attendant of the life proposed to be insured, it being contrary to the general practice of the insarance offices to do so. "I am, \&c.,

"R. Painter, Esq."

"C. H. Lidderdale."

On making inquiries of Mr. A-, I find his proposal was accepted on the 5th, before two P.M., some hours before $\mathrm{Mr}$. Lidderdale's letter to me was posted, thereby preventing my recommending $\mathrm{Mr}$. A - to apply to another office. $\mathrm{Mr}$. A - was told that I had refused to answer the questions, but my reason for not doing so was not given.

I remain, Sir, your obedient servant,

\section{Richard Painter.}

\section{The Clemicat and Medioal Life Assurance Office.} To the Editor of The LaNCET.

Sin,-The following is a copy of a letter sent by me to the goent of the Medical and Clerical Life Assurance Office. You will see I have declined on one occasion before, but the patient was examined by another medical man, who passed him. Had the office possessed my information, they might have rejected him.

I am, Sir, yours \&c., W. S. BARKER.

"Sir,-Some time since you forwarded me a set of questions to be answered, respecting the life of a person in this neighbourhood, and which I declined to answer, as no fee was sent, or my information might have prevented the assurance of his life. I beg for the same reason to decline filling up the forms you have now sent me, in the cases of $\mathrm{Mr}$. Thomas $\mathrm{C}$ - and Mrs. F. C-.

"To Mr. Pinckhard."

$$
\text { I am, Sir, yours \&c., }
$$

* * Thus do some offices, for the sake of saving an insignificant fee, preclude themselves from obtaining a report from the best source-the medical attendant of the party desirous to assure, and which would naturally form their surest means of guidance as to the acceptation or rejection of the life proposed for assurance. Such indifference is neither wise nor just towards the parties pecuniarily interested in the prosperity of the office; wisdom and justice in such a matter are indeed inseparable.-ED. L.

\section{ACTION OF CHLOROFORM. To the Editor of THE Lancet.}

SIR,-I have perused with extreme interest and satisfaction a report of the paper on the Inhalation of Chloroform, read by Mr. Dunn at the meeting of the Royal Medical and Chirurgical Society, held on the 22nd of April last. Every one must, I think, admit that the author has given a most lucid exposition of the physiology of the nervous system in its most recent form; yet, having administered the chloroform at this hospital on very many occasions, I cannot, though fully agreeing with the learned author as to the great value of the agent as an anæsthetic, concur with him in his description of the systematic manner in which the agent produces its effects upon the nervous centres and their functions. As far as I have observed, the operation of chloroform is twofold, its primary action being that of a powerful stimulant, and so far from the motor function being arrested in the first instance, we have frequently found it violently excited, the patient requiring to be forcibly held to keep him quietly upon the operating table, the intellectual functions being at the same time in a state analagous to delirium. A perseverance in the application of the remedy, however, soon produces a very opposite condition-the stage, I should call it, of true anrsthesia where the patient lies in a condition resembling profound sleep, where all sensation and voluntary motion is lost, and during which the heart's action is lowered, and, as I think the blood congested in the heart and the great vessels. That the nutritive, secretory, or ganglionic system does not entirely escape, is evident from what takes place in what may be called the reactionary stage, in which $I$ have observed vomiting to be the most frequent and general accompaniment. I am in. clined, upon the whole, to believe that the action of chloroform assimilates in a remarkable degree to that of a powerful intoxicating agent, for drunkenness is a condition in which there is a considerable immunity to pain, as I have heard men in a state of intoxication, when wounded or injured, exclaim, "You may cut me or do as you like;" and I have found this to be no idle boast, as they have borne their sufferings exceed. ingly well. The difference is in this-the effects of the chloroform pass off very readily, whereas in drunkenness it requires hours to do so: this makes the chloroform so manageable and safe an agent, and hence, being free also from the moral debasement, its paramount advantage and utility in surgical operations. One great advantage of this agent should not be overlooked - viz. that it makes your patient as manageable as ever you please; this, in the case of children, is a great point gained, where the cries and struggles of the little patient frequently add much to the anxiety and difficulty of the operation; and I may add, that I think chloroform is capable of rendering essential service in the treatment of dislocations. I well remember one case, under the care of the late $\mathbf{M r} . \mathbf{R}$. Craven, where, in a dislocation of the head of the femur into the ischiatic notch, the slightest traction when the patient was placed in a state of insensibility was sufficient to restore the head of the dislocated bone to its natural position.

In conclusion, I may say that the practice of this institution fully justifies the high position which the use of chloroform has attained as the most valuable adjuvant known in the modern practice of surgery. - I am, Sir, your obedient servant, Hull Infirmary, May, 1851. T. T. LAMBERT, House-Surgeon.

\section{MEETINGS OF THE MEDICAL SOCIETIES IN} LONDON DURING THE ENSUING WEEK.

Norg.-When the day of the month is not specified, no meetings take place.

Societies.

\section{Epidemiological}

Chemical, 142, Strand

Medico-Botanical, 32, Sackville-st.

Medico-Chirurgical, 53, Berners-st.

Pathological, 32A, George-street, Hanover-square.

Hunterian, 4, Bloonfield-street, Finsbury ............................ Pharmaceutical, 17, Bloomsbury-sq Harveian, 21, Edwards-street, Portman-square South London Medicaî, Borough .... Western Medical and Surgical...... Medical Society of London, 32A, George-street, Hanover-square

\begin{tabular}{|c|c|}
\hline & $\begin{array}{c}\text { Days of } \\
\text { Meeting. }\end{array}$ \\
\hline $\begin{array}{l}\text { Mon. } 8 \frac{1}{2} \text { P.M. } \\
\text { Mon. } 8 \text { P.M. } \\
\text { Tuesday. } \\
\text { Tues. } 8 \frac{1}{2} \text { P.M. }\end{array}$ & $\begin{array}{c}\text { June } 16 \\
\Rightarrow 17 \\
\text { " } 24\end{array}$ \\
\hline Tues. 8 P.M. & $\Rightarrow 17$ \\
\hline
\end{tabular}

Wed. 8 P.M. Wed. 9 P.M. Thurs. 8 P.N. Thurs. 8 P.M. Fri. 8 P.M. Sat. 8 P.M. 